\title{
Speciation of Main Nutrients (N/P/K) in Hydrochars Produced from the Hydrothermal Carbonization of Swine Manure under Different Reaction Temperatures
}

\author{
Jiangbo Xiong ${ }^{1, *}$, Shuaiwei Chen ${ }^{2}$, Jiaxin Wang ${ }^{1}$, Yujie Wang ${ }^{1}$, Xiaolin Fang ${ }^{1}$ and Huajun Huang ${ }^{1, *(D)}$ \\ 1 School of Land Resources and Environment, Key Laboratory of Agricultural Resource and Ecology in the \\ Poyang Lake Basin of Jiangxi Province, Jiangxi Agricultural University, Nanchang 330045, China; \\ 9707xinlang@sina.com (J.W.); wyj1649757125@126.com (Y.W.); fx113870703704@163.com (X.F.) \\ 2 School of Forestry, Fujian Agriculture and Forestry University, Fuzhou 350002, China; \\ fjnlchenshuaiwei@163.com \\ * Correspondence: xiongjiangbo@jxau.edu.cn (J.X.); huajunhuang@jxau.edu.cn (H.H.); \\ Tel.: +86-791-83828028 (H.H.); Fax: +86-791-83828028 (H.H.)
}

\section{check for} updates

Citation: Xiong, J.; Chen, S.; Wang, J.; Wang, Y.; Fang, X.; Huang, H. Speciation of Main Nutrients $(\mathrm{N} / \mathrm{P} / \mathrm{K})$ in Hydrochars Produced from the Hydrothermal Carbonization of Swine Manure under Different Reaction Temperatures. Materials 2021, 14, 4114. https://doi.org/10.3390/ma14154114

Academic Editor: José Rodríguez Mirasol

Received: 24 June 2021

Accepted: 20 July 2021

Published: 23 July 2021

Publisher's Note: MDPI stays neutral with regard to jurisdictional claims in published maps and institutional affiliations.

Copyright: (c) 2021 by the authors. Licensee MDPI, Basel, Switzerland. This article is an open access article distributed under the terms and conditions of the Creative Commons Attribution (CC BY) license (https:// creativecommons.org/licenses/by/ $4.0 /)$.

\begin{abstract}
Hydrothermal carbonization (HTC) has been proved to be a promising technology for swine manure (SM) treatment. Currently, there is a lack of systematic understanding of the transformation characteristics of nutrient speciation in the HTC of SM. In this study, the speciation of the main nutrients $(\mathrm{N} / \mathrm{P} / \mathrm{K})$ in $\mathrm{SM}$-derived hydrochar produced at different reaction temperatures $\left(200-280^{\circ} \mathrm{C}\right)$ was investigated. The recovery of $\mathrm{P}(61.0-67.1 \%)$ in hydrochars was significantly higher than that of $\mathrm{N}(23.0-39.8 \%)$ and $\mathrm{K}(25.5-30.0 \%)$, and the increase in reaction temperature promoted the recovery of $\mathrm{P}$ and reduced the recovery of $\mathrm{N}$. After the HTC treatment, the percentage of soluble/available $\mathrm{P}$ was reduced from $61.6 \%$ in raw SM to $4.0-23.9 \%$ in hydrochars, while that of moderately labile/slowrelease $\mathrm{P}$ was improved from $29.2 \%$ in raw SM feedstock to $65.5-82.7 \%$. An obvious reduction was also found in the amounts of available N (from 51.3\% in raw SM feedstock to 33.0-40.5\% in hydrochars). The percentages of slow-release $\mathrm{N}$ and residual $\mathrm{N}$ in hydrochars produced at $240{ }^{\circ} \mathrm{C}$ reached the maximum and minimum values (46.4\% and $18.9 \%$ ), respectively. A total of $49.5-58.3 \%$ of $\mathrm{K}$ retained in hydrochars was residual (invalid) potassium. From the perspective of the mobility and availability of N, P and K only, it was suggested that the HTC of SM should be carried out at 220-240 ${ }^{\circ} \mathrm{C}$. Compared with the original SM, it is safer and more effective to use the SM-derived hydrochar as an organic fertilizer.
\end{abstract}

Keywords: swine manure; hydrothermal carbonization; hydrochar; nutrients; speciation

\section{Introduction}

Livestock production usually generates enormous amounts of manure waste, which demand adequate disposal strategies due to their polluting potentials (e.g., eutrophication, pathogens, antibiotics, and heavy metals) [1,2]. China is the largest pig producer in the world with an average pig rearing amount of 449 million heads per year, accounting for $50 \%$ of the total global production [3]. The annual output of livestock manure in China has reached 3.8 billion tons, of which swine manure (SM) accounts for 38.3\% [4]. At present, researchers have developed a series of technologies for the treatment/disposal of SM (a wet solid waste), mainly including composting [5,6], anaerobic digestion $[7,8]$, hydrothermal carbonization (HTC) [9-11], pyrolysis [12,13], gasification [14,15], and liquefaction [16,17].

HTC, a thermochemical conversion technology, can convert SM into a carbon-rich solid product (hydrochar) under relatively mild temperatures (usually lower than $300{ }^{\circ} \mathrm{C}$ ) and autogenous pressure for a stipulated residence time [18]. Hydrochar is a kind of multifunctional material, and its application includes use as an adsorbent, for soil remediation/improvement, as fuel, as a carbon-sequestering biochar, and as a substitute 
for carbon black and activated carbon [19]. During the HTC process, SM is converted with water as a solvent by a series of reactions such as condensation, polymerization, hydrolysis, decarboxylation, dehydration, and aromatization [20]. In other words, no predewatering/drying is needed for the HTC process as required in other thermal treatment processes (e.g., pyrolysis, dry gasification, and combustion), which makes it an economically attractive option for the treatment of SM [19]. Generally speaking, the research on the HTC of SM has been currently carried out regarding the following aspects: (i) the effects of the main process parameters, including reaction temperature/time, solid-liquid ratio, catalyst and heating mode, on the yield/property of hydrochar [21-25]; (ii) the Co-HTC of SM and lignocellulosic biomass [26-28]; (iii) the migration and transformation of pollutants (heavy metals and PAHs) existed in raw SM [10,29,30]; (iv) inter-comparison of the properties of hydrochar and biochar (pyrolysis) [9,31-33]; and (v) the fate of nutrients contained in raw SM $[4,23,34,35]$.

Nitrogen and phosphorus are the main contributors to the eutrophication of water bodies due to the high release rate of phosphorus and nitrogen in inorganic fertilizers used in agriculture [36]. It has been reported that most of the $\mathrm{N}(70-80 \%), \mathrm{P}(60-85 \%)$ and $\mathrm{K}$ $(80-90 \%)$ in animal diets eventually were transferred to the feces [37]. Thus, SM-derived hydrochar has the potential to be used as organic fertilizer and to solve the problem of nitrogen and phosphorus loss. [23]. Of note, the recycling efficiency of nutrients in hydrochar is greatly influenced by the content and speciation of each nutrient, which ultimately determines the overall quality of hydrochar fertilizer to a large extent [34]. As mentioned above, some studies have been carried out on the fate of nutrients during the HTC of SM, but the focus is primarily on the total content of nutrients retained in hydrochar $[23,27,31-33]$. A few researchers have also paid attention to the contents of nitrate $\mathrm{N}$, ammonium $\mathrm{N}$, available $\mathrm{P}$, and available $\mathrm{K}$ in SM-derived hydrochars [4,21,22]. In the research by Huang et al. [34], the transformations of $\mathrm{P}$ speciation (including five forms) were explored during the HTC of SM. However, to date, the transformations of N/K speciation during the HTC of SM are still unclear. It is hypothesized that the speciation of N/K would also be changed during the HTC of SM, which is significant for a full understanding of nutrient recovery in SM-derived hydrochars.

The information about the distributions of N/K speciation in SM-derived hydrochars should be further studied. In this work, the transformation characteristics of main nutrients $(\mathrm{N}, \mathrm{P}$, and $\mathrm{K})$ speciation were systematically investigated during the HTC of SM. Meanwhile, the recovery rates of $\mathrm{N}, \mathrm{P}$, and $\mathrm{K}$ were also explored to reflect the overall situation of nutrient recovery. Such information can further guide the selection of process conditions for the HTC of SM from the view of nutrient recovery.

\section{Materials and Methods}

\subsection{Materials}

Fresh SM feedstock was collected from a pig farm near Jiangxi Agricultural University (Nanchang, China). In this preliminary research work, SM feedstock was thoroughly dried to accurately control the amount of solvent (water) used in the HTC process. Specifically, the fresh SM feedstock was firstly air-dried and then transferred to an oven (BPG-9156b, Yiheng, Shanghai, China) for thorough drying (at $105{ }^{\circ} \mathrm{C}$ overnight). The dried SM feedstock was crushed, and the samples below 40 mesh were collected. The pretreated SM feedstock was stored in a sealed glass bottle and stored in a desiccator. Some important metals in raw SM feedstock, such as calcium, magnesium, sodium, iron, manganese, and aluminum, were analyzed using an inductively coupled plasma-atomic emission spectrometry (ICP Prodigy $\mathrm{XP}$, Leeman, Hudson, NH, USA) following acid digestion in nitric acid. All measurements were performed thrice and the mean values with standard deviation (SD) are reported in Table 1. 
Table 1. Some important metal contents in raw SM feedstocks.

\begin{tabular}{ccccccc}
\hline \multirow{2}{*}{ Items } & \multicolumn{6}{c}{ Concentrations $(\mathbf{m g} / \mathbf{g}$, Dry Basis) } \\
\cline { 2 - 7 } & $\mathbf{C a}$ & $\mathbf{M g}$ & $\mathbf{F e}$ & $\mathbf{M n}$ & $\mathbf{A l}$ & $\mathbf{N a}$ \\
\hline $\mathrm{SM}$ & $17.16 \pm 0.25$ & $7.88 \pm 0.08$ & $6.93 \pm 0.51$ & $0.63 \pm 0.02$ & $5.96 \pm 0.33$ & $4.52 \pm 0.34$ \\
\hline
\end{tabular}

\subsection{HTC Experiments}

The HTC of SM was carried out in a batch reactor (4566, Parr, Moline, IL, USA). In brief, according to the solid-liquid ratio, a certain amount of SM and water were firstly mixed then added to the reactor, and then the reaction was carried out at the desired reaction temperature/time. After the end of the reaction, solid-liquid separation was carried out. Solid-state products were dried, and the yield was calculated. For the detailed HTC process procedure, we referred to the previous work of the authors in [22]. In this work, hydrochar was obtained from the HTC of SM at five different reaction temperatures $\left(200{ }^{\circ} \mathrm{C}, 220^{\circ} \mathrm{C}, 240^{\circ} \mathrm{C}, 260^{\circ} \mathrm{C}\right.$, and $\left.280^{\circ} \mathrm{C}\right)$. The solid-liquid ratio and reaction time were fixed at $0.1 \mathrm{~g} / \mathrm{mL}$ and $30 \mathrm{~min}$, respectively. It should be emphasized that the reaction time only referred to the reaction duration after the reaction system reached the set reaction temperature, excluding the heating and cooling time.

\subsection{Speciation Analysis of $\mathrm{N} / \mathrm{P} / \mathrm{K}$}

Procedures for speciation analysis of nutrient elements $(\mathrm{N} / \mathrm{P} / \mathrm{K})$ in raw $\mathrm{SM}$ and hydrochars are shown in Figure 1. All analysis experiments were carried out three times.

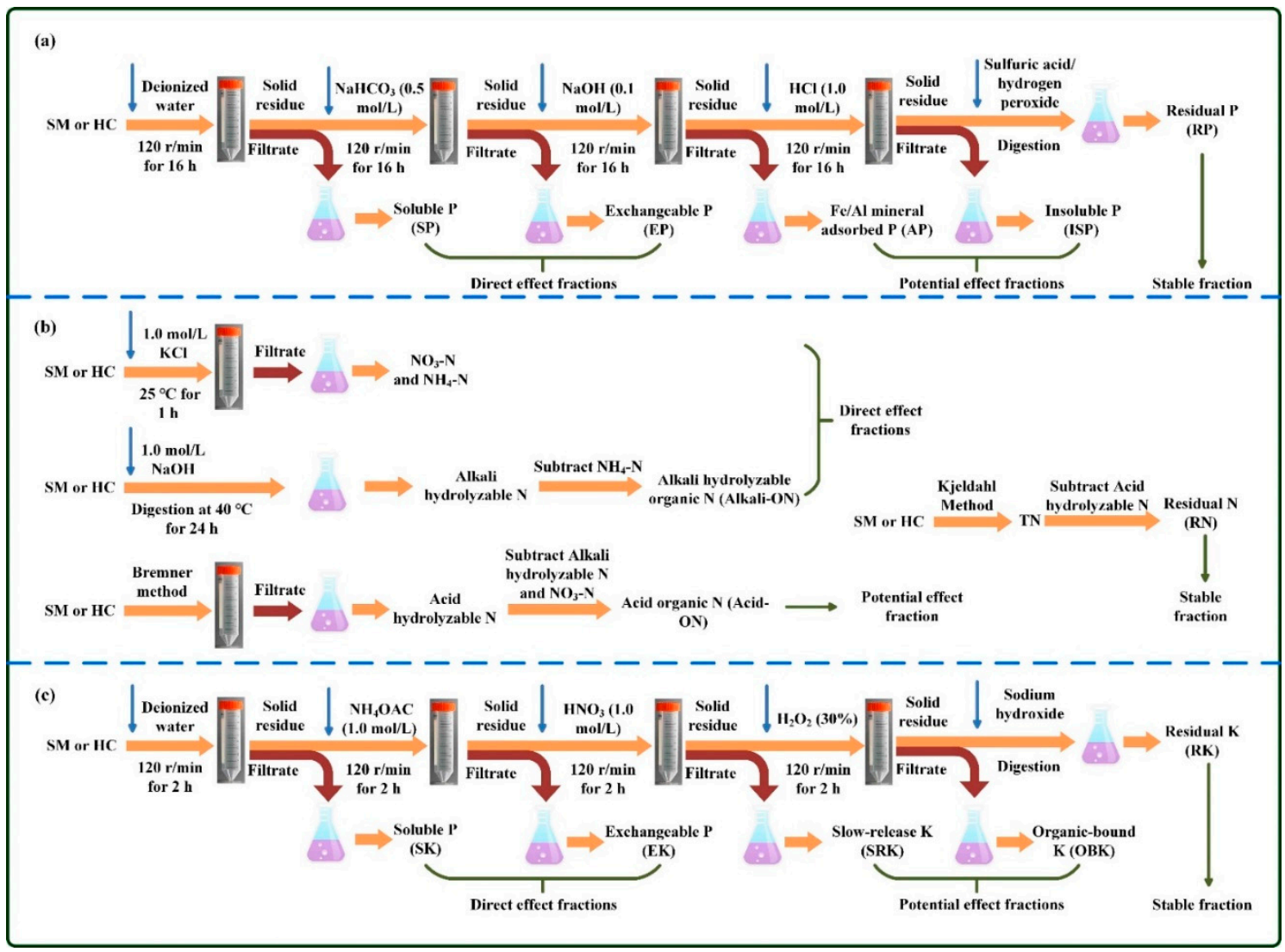

Figure 1. Extraction methods of different chemical forms of phosphorus (a), nitrogen (b) and potassium (c). 


\subsubsection{Speciation of Phosphorus (P)}

According to the theory of Hedley's method [34], the speciation of phosphorus (P) includes soluble $\mathrm{P}(\mathrm{SP})$, exchangeable $\mathrm{P}(\mathrm{EP}), \mathrm{Fe} / \mathrm{Al}$ mineral adsorbed $\mathrm{P}(\mathrm{AP})$, insoluble phosphates (ISP), and residual P (RP) (Figure 1a). The contents of SP, EP, AP, and ISP are defined as the amounts of $\mathrm{P}$ sequentially extracted by water, $\mathrm{NaHCO}_{3}, \mathrm{NaOH}$, and $\mathrm{HCl}$, respectively. Specifically, $0.1 \mathrm{~g}$ of raw SM or $0.2 \mathrm{~g}$ of hydrochar was placed into a $50 \mathrm{~mL}$ polypropylene centrifuge tube, which was sequentially extracted by $20 \mathrm{~mL}$ extraction solutions, including deionized water, $\mathrm{NaHCO}_{3}(0.5 \mathrm{~mol} / \mathrm{L}), \mathrm{NaOH}(0.1 \mathrm{~mol} / \mathrm{L})$ and $1.0 \mathrm{HCl}$ $(1.0 \mathrm{~mol} / \mathrm{L})$. For each extraction, the mixture oscillated at $120 \mathrm{r} / \mathrm{min}$ for $16 \mathrm{~h}$. After the end of each extraction, the mixture was centrifuged and then filtered with a $0.45 \mu \mathrm{m}$ membrane. The digestion of filtrate was conducted with the aid of persulfate, and then the concentration of $\mathrm{P}$ was determined by an ammonium molybdate colorimetric spectrophotometer (DR5000, HACH, Loveland, CO, USA). The residual solids after all extraction were digested with sulfuric acid/hydrogen peroxide solutions, and then the concentration of $\mathrm{P}$ in the digestion solution was detected using the method described above, which was defined as RP. The content of total phosphorous (TP) was estimated by adding all of the above speciation of $P$.

\subsubsection{Speciation of Nitrogen $(\mathrm{N})$}

The speciation of $\mathrm{N}$ was roughly divided into available, slow-release and residual forms (Figure $1 \mathrm{~b}$ ). The available $\mathrm{N}$ includes inorganic available $\mathrm{N}$ (mainly $\mathrm{NO}_{3}-\mathrm{N}$ and $\mathrm{NH}_{4}-\mathrm{N}$ ) and organic available $\mathrm{N}$. To determine the content of $\mathrm{NO}_{3}-\mathrm{N}$ and $\mathrm{NH}_{4}-\mathrm{N}$, the raw SM feedstock or hydrochar samples were extracted by $1.0 \mathrm{~mol} / \mathrm{L} \mathrm{KCl}$ at $25^{\circ} \mathrm{C}$ for $1 \mathrm{~h}$, and then the corresponding concentrations were detected with the aid of a continuous flow autoanalyzer (AA3, Seal, Norderstedt, Germany). The content of organic available $\mathrm{N}$ was defined as the difference between alkali hydrolyzable $\mathrm{N}$ and $\mathrm{NH}_{4}-\mathrm{N}$, also called alkali hydrolyzable organic $\mathrm{N}$ (Alkali-ON). The content of alkali hydrolyzable $\mathrm{N}$ was determined with the method of $\mathrm{NaOH}$ hydrolyzation diffusion $\left(1.0 \mathrm{~mol} / \mathrm{L}\right.$, at $40{ }^{\circ} \mathrm{C}$ for $24 \mathrm{~h}$ ) followed by boric acid titration [22]. The content of slow-release $\mathrm{N}$ was estimated by subtracting alkali hydrolyzable $\mathrm{N}$ and $\mathrm{NO}_{3}-\mathrm{N}$ from acid hydrolyzable $\mathrm{N}$, also called acid organic $\mathrm{N}$ (Acid-ON). The content of acid hydrolyzable $\mathrm{N}$ was measured according to the Bremner method, which is as follows: firstly, extraction with $6 \mathrm{~mol} / \mathrm{L}$ hydrochloric acid; secondly, digestion with sulfuric acid and catalyst $\left(\mathrm{K}_{2} \mathrm{SO}_{4}-\mathrm{CuSO}_{4}\right.$-Se powder); and lastly, detection with distilled/semi-micro titration [38]. The content of residual $\mathrm{N}(\mathrm{RN})$ was defined as the fraction of non-hydrolyzable nitrogen, which was estimated by subtracting acid hydrolyzable $\mathrm{N}$ from total nitrogen (TN). The content of $\mathrm{TN}$ was determined by the standard Kjeldahl method with the aid of a Kjeldahl apparatus (K1160, Hanon, Jinan, China) [35].

\subsubsection{Speciation of Potassium (K)}

In general, the speciation of $\mathrm{K}$ consists of soluble $\mathrm{K}$ (SK), exchangeable $\mathrm{K}$ (EK), slowrelease K (SRK), organic-bound K (OBK), and residual K (RK) (Figure 1c). The contents of SK, EK, SRK, and OBK were defined as the amounts of K extracted by water, ammonium acetate, nitric acid, and hydrogen peroxide in turn, respectively [39-42]. In particular, $0.1 \mathrm{~g}$ of raw SM feedstock or $0.2 \mathrm{~g}$ of hydrochar was placed into a $50 \mathrm{~mL}$ polypropylene centrifuge tube, which was sequentially extracted by $20 \mathrm{~mL}$ extraction solutions, including deionized water, $\mathrm{NH}_{4} \mathrm{OAC}(1.0 \mathrm{~mol} / \mathrm{L}), \mathrm{HNO}_{3}(1.0 \mathrm{~mol} / \mathrm{L})$, and $\mathrm{H}_{2} \mathrm{O}_{2}(30 \%)$. For each extraction process, the mixture oscillated at $120 \mathrm{r} / \mathrm{min}$ for $2 \mathrm{~h}$. After the end of each extraction process, the mixture was centrifuged and then filtered with a $0.45 \mu \mathrm{m}$ membrane. The concentration of $\mathrm{K}$ in each filtrate was detected by the method of flame photometer (FP 640, AOPU, Shanghai, China). The residual solids after all extraction were digested with sodium hydroxide, and then the concentration of potassium in the digestion solution was detected according to the method mentioned above, which was defined as RK. The content of total potassium (TK) was calculated as the sum of all the above speciation of $\mathrm{K}$. 


\subsection{Definition}

The recovery rate $(R R, \%)$ of nutrients $(\mathrm{N}, \mathrm{P}$, and $\mathrm{K})$ in hydrochars was calculated according to Equation (1).

$$
R R=\frac{C_{H C}^{T C-i} \times Y_{H C-T}}{C_{S M}^{T C-i}} \times 100
$$

where $C_{H C}^{T C-i}$ is the total content of one nutrient in hydrochars (mg/g, dry basis); $C_{S M}^{T C-i}$ is the total content of one nutrient in raw SM (mg/g, dry basis); and $Y_{\mathrm{HC}-\mathrm{T}}$ is the yield of hydrochar obtained at one reaction temperature (wt.\%), which was described in a previous paper of the authors [22].

\section{Results and Discussions}

\subsection{Recovery Rate of $\mathrm{N} / \mathrm{P} / \mathrm{K}$}

The recovery rates of three main nutrients $(\mathrm{N}, \mathrm{P}$, and $\mathrm{K})$ in hydrochars obtained at different reaction temperatures are shown in Figure 2. A higher recovery rate, 61.0-67.1\%, was found for $\mathrm{P}$, while the recovery rates of $\mathrm{N}$ and $\mathrm{K}$ were relatively low, distributed in the ranges of $23.0-39.8 \%$ and $25.5-30.0 \%$, respectively. In addition, the effect of the increase in reaction temperature on the recovery rate of each nutrient element was also not consistent. The recovery rate of $\mathrm{P}$ increased overall with the increase in reaction temperature, while that of $\mathrm{N}$ showed an opposite trend. The recovery rate of $\mathrm{K}$ in hydrochar obtained at $220^{\circ} \mathrm{C}$ was the lowest $(25.5 \%)$. As shown in Tables $2-4$, the total content of TP in hydrochar increased with the increase in reaction temperature, while that of TN decreased gradually, and that of TK was the lowest at $220^{\circ} \mathrm{C}$. Considering that the yield of hydrochar has the same effect on the recovery rate of different nutrients, the recovery rate results depicted in Figure 2 were reasonable.

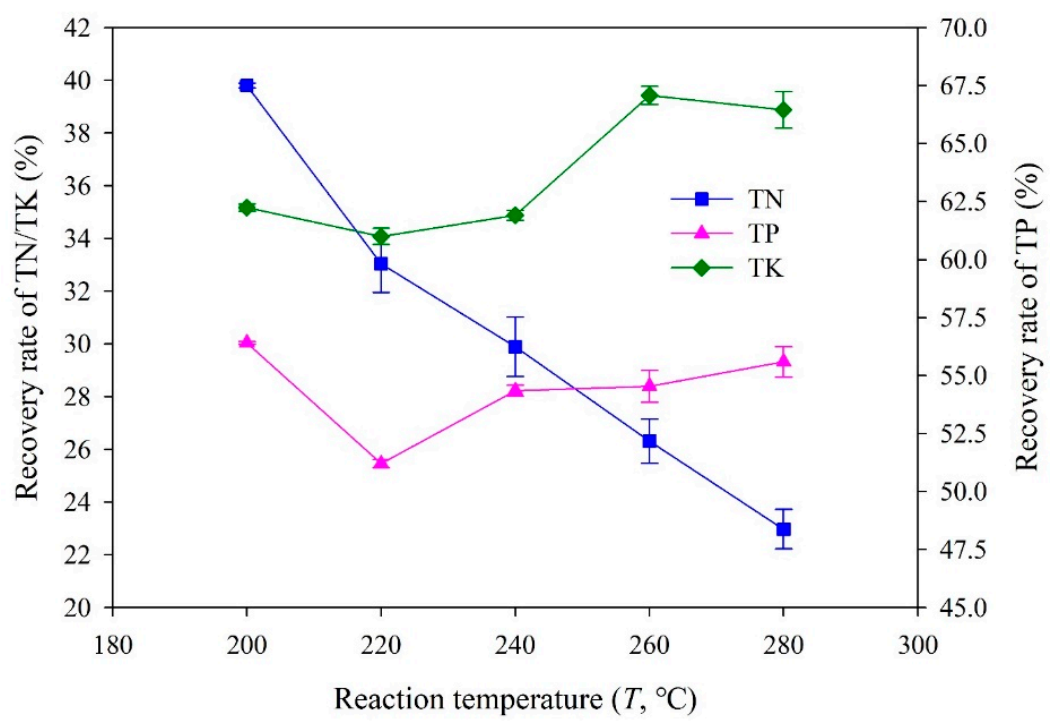

Figure 2. Recovery rate of nutrients in hydrochars obtained at different reaction temperatures.

Higher reaction temperatures may decrease $\mathrm{N}$ recovery to the hydrochar via enhancing deamination reactions, which cause the transportation of $\mathrm{N}$-compounds to the aqueous product (process water) and promotion of the transportation rate of $\mathrm{N}$ to the gaseous phase [43]. Regarding $P$ recovery, the increase in reaction temperature improved the formation of metal-associated P species (e.g., calcium, aluminum, magnesium, or iron) and insoluble phosphates, as well as potential physical constraints (e.g., embedment of $\mathrm{P}$ species into the char structure) [44,45]. K has a larger water solubility compared to N/P and is a less reactive element. Therefore, on the one hand, the recovery rate of $\mathrm{K}$ in hydrochars 
was relatively low, and on the other hand, the increase in reaction temperature did not bring a significant change to the recovery rate of K [46].

\subsection{Transformations of $P$ Speciation}

The content of P present in each form is listed in Table 2. The changes in the proportions of $\mathrm{P}$ distributed in different forms between the raw SM feedstock and hydrochars are shown in Figure 3.

Table 2. Different forms of phosphorus in raw SM and hydrochars obtained at different reaction temperatures (mg/g, dry basis).

\begin{tabular}{ccccccc}
\hline Sample & SP & EP & AP & ISP & RP & $\sum$ (TP) \\
\hline SM & $10.66 \pm 0.07$ & $5.27 \pm 0.06$ & $2.49 \pm 0.03$ & $5.06 \pm 0.04$ & $2.38 \pm 0.15$ & $25.86 \pm 0.35$ \\
HC-200 & $2.73 \pm 0.01$ & $3.83 \pm 0.02$ & $4.67 \pm 0.25$ & $13.29 \pm 0.08$ & $2.89 \pm 0.07$ & $27.41 \pm 0.44$ \\
HC-220 & $2.62 \pm 0.01$ & $2.70 \pm 0.01$ & $4.83 \pm 0.13$ & $14.77 \pm 0.02$ & $3.49 \pm 0.05$ & $28.41 \pm 0.22$ \\
HC-240 & $1.47 \pm 0.02$ & $1.74 \pm 0.03$ & $3.01 \pm 0.05$ & $20.83 \pm 0.04$ & $3.05 \pm 0.16$ & $30.10 \pm 0.30$ \\
HC-260 & $0.52 \pm 0.02$ & $1.61 \pm 0.01$ & $1.59 \pm 0.02$ & $24.08 \pm 0.45$ & $4.83 \pm 0.13$ & $32.63 \pm 0.63$ \\
HC-280 & $0.44 \pm 0.04$ & $0.92 \pm 0.01$ & $1.01 \pm 0.02$ & $27.29 \pm 0.52$ & $4.56 \pm 0.28$ & $34.22 \pm 0.87$ \\
\hline
\end{tabular}

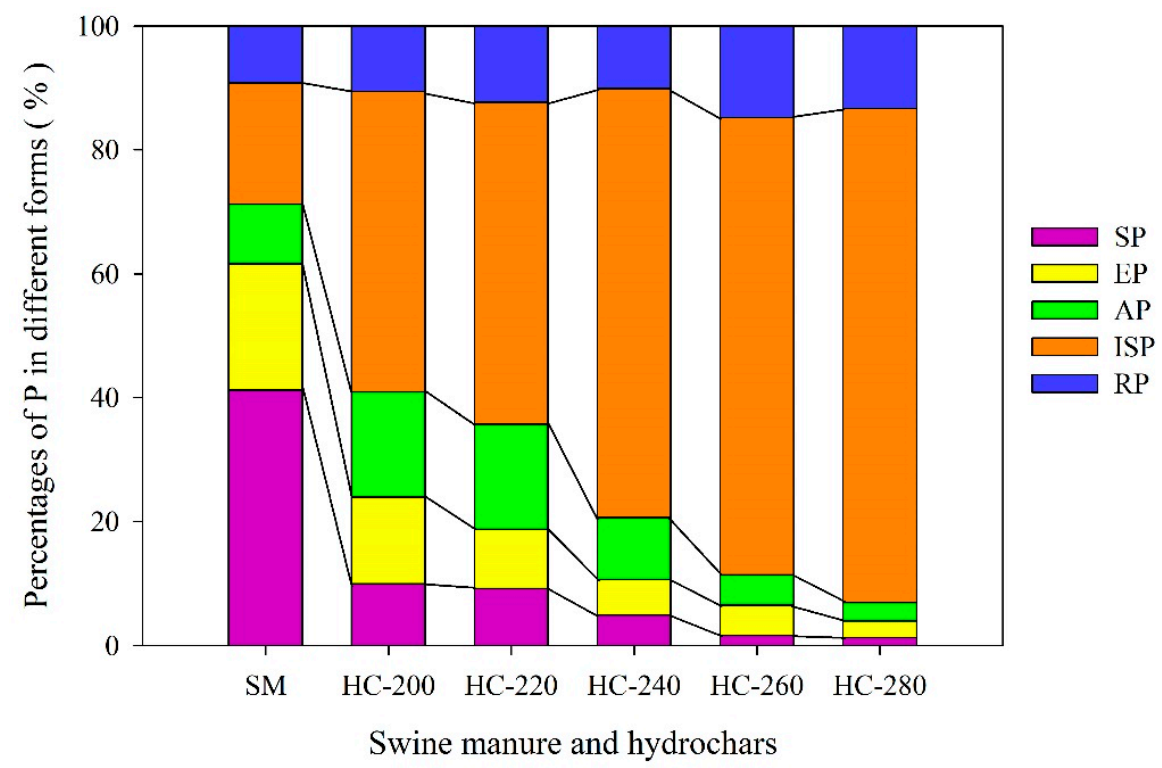

Figure 3. Changes in the forms of $\mathrm{P}$ between raw SM and hydrochars obtained at different reaction temperatures.

\subsection{1. $\mathrm{H}_{2} \mathrm{O}$-Extractable $\mathrm{P}(\mathrm{SP})$ and $\mathrm{NaHCO}_{3}$-Extractable $\mathrm{P}$ (EP)}

As seen from Figure 3, about $61.6 \%$ of $\mathrm{P}$ in the raw SM feedstock can be extracted by $\mathrm{H}_{2} \mathrm{O}(\mathrm{SP})$ and $\mathrm{NaHCO}_{3}(\mathrm{EP})$, indicating that $\mathrm{P}$ contained in raw SM feedstock was highly mobile. The high percentage of mobile $\mathrm{P}$ in raw SM feedstock can largely be attributed to the presence of relatively soluble $P$ species in fresh manure, such as various organic phosphates, soluble phosphates (such as $\mathrm{Na}$ and $\mathrm{K}$ phosphates) and soluble $\mathrm{Ca}$ phosphate species $[47,48]$. The content of SP in hydrochars reduced sharply with increasing reaction temperature, from $2.73 \pm 0.01 \mathrm{mg} / \mathrm{g}$ at $200{ }^{\circ} \mathrm{C}$ to $0.44 \pm 0.04 \mathrm{mg} / \mathrm{g}$ at $280{ }^{\circ} \mathrm{C}$, which decreased by $74.4 \%$ and $95.9 \%$ compared with that in raw SM $(10.66 \pm 0.07 \mathrm{mg} / \mathrm{g})$, respectively. It was also observed that the proportion of SP decreased from $41.2 \%$ for raw SM to less than $10.0 \%$ for all hydrochars, which was almost negligible at reaction temperatures higher than $260{ }^{\circ} \mathrm{C}$ (less than $2.0 \%$ ) (Figure 3). These results show that the HTC treatment could greatly reduce the amount of SP in hydrochar, and thus reduce the risk of $\mathrm{P}$ loss when it was applied to the soil. 
The contents of EP in hydrochars were in the range of $0.92-3.83 \mathrm{mg} / \mathrm{g}$, much lower than those in raw SM $(5.27 \pm 0.06 \mathrm{mg} / \mathrm{g})$. Furthermore, they continuously decreased with the increase in reaction temperatures and, particularly at $280{ }^{\circ} \mathrm{C}$, they decreased by $82.5 \%$ compared with those in the raw SM feedstock. Considering that EP was a kind of biologically available $\mathrm{P}$, it can be concluded that the HTC treatment reduced the bioavailability of $\mathrm{P}$, and the higher the reaction temperature, the lower the bioavailability of $\mathrm{P}$ in hydrochars. In addition, as seen in Table 2, the content of SP in hydrochar obtained at $200{ }^{\circ} \mathrm{C}$ decreased by $74.4 \%$ compared with that in the raw SM feedstock, which was close to the decline range of $\mathrm{EP}$ in hydrochar produced at $260{ }^{\circ} \mathrm{C}(69.4 \%)$. This result suggests that the SP was more sensitive to reaction temperature compared to EP. In general, the reduction of SP and EP might be caused by the formation of non-apatite $\mathrm{P}$ and apatite $\mathrm{P}$. This inference has been verified in prior studies $[24,49,50]$.

\subsection{2. $\mathrm{NaOH}$-Extractable $\mathrm{P}$ (AP)}

The percentage of $\mathrm{NaOH}$-extractable $\mathrm{P}(\mathrm{AP})$ in raw SM feedstock was small $(<10 \%)$, indicating a low content of $\mathrm{Fe} / \mathrm{Al}$ mineral adsorbed $\mathrm{P}$ species $(2.49 \pm 0.03 \mathrm{mg} / \mathrm{g})$. At lower HTC reaction temperatures $\left(200-240^{\circ} \mathrm{C}\right)$, the contents of AP in hydrochars were higher than those in raw SM feedstock. However, with the further increase in HTC reaction temperature $\left(260-280{ }^{\circ} \mathrm{C}\right)$, the contents of AP in hydrochars were lower (Table 2). Accordingly, the proportions of AP in hydrochars continuously declined from $17.0 \%$ to $3.0 \%$ with the increase in reaction temperature (Figure 3). As mentioned, AP was mainly adsorbed on the surface of $\mathrm{Fe} / \mathrm{Al}$ minerals in manure through chemical adsorption, including inorganic and organic parts, which was a moderately labile P [51]. Thus, the existence of AP was largely related to the concentration of $\mathrm{Fe} / \mathrm{Al}$ cations. It was deemed that $\mathrm{Fe} / \mathrm{Al}$ cations can replace $\mathrm{K} / \mathrm{Na}$ ions to form precipitation at low HTC reaction temperatures, increasing the content of AP in hydrochar, while as the HTC reaction temperature continued to rise, $\mathrm{Fe} / \mathrm{Al}$ cations may be replaced by calcium ion to form apatite phosphorus or be coated with calcium phosphate, leading to the decrease in AP content [52]. Additionally, the increase in HTC reaction temperature would also accelerate the degradation of organophosphorus, resulting in the decrease in AP in hydrochars to some extent [34].

\subsubsection{HCl-Extractable P (ISP) and Residual P (RP)}

The HCl-extractable P (ISP) was the apatite $\mathrm{P}$ fraction, which is a stable form of $\mathrm{P}$ and assumed to be associated with $\mathrm{Ca}$ [51]. The percentage of ISP in raw SM feedstock was $19.6 \%$, with the contribution of the insoluble $\mathrm{Al}$ and $\mathrm{Ca}$ phosphate phases. The content of ISP in hydrochars increased dramatically with the increase in HTC reaction temperature, by 1.6-4.4 times compared with that in the raw SM feedstock (Table 2). Thus, the proportions of ISP in hydrochars were up to $48.5-79.8 \%$, much higher than those in raw SM (19.6\%), and increased with increasing reaction temperatures (Figure 3 ). These results suggest that although P was concentrated in the hydrochars (Figure 1), the amount of insoluble P tended to increase remarkably after the HTC treatment. In other words, the raw SM feedstock was transformed into slow-release phosphate fertilizer by the HTC treatment. The increase in ISP can be explained from the following three aspects: (i) calcium was the main cation in raw SM feedstock, which could provide a prerequisite for the formation of calciumcontaining phosphate; (ii) under hydrothermal conditions, calcium and orthophosphate can form calcium-containing phosphate with different solubility and stability, such as amorphous-, crystalline- and hydroxyapatite-calcium; and (iii) the degree of dissolution, reprecipitation and/or crystallization of calcium-containing phosphate were also affected by the reaction temperature. A higher HTC reaction temperature was conducive to the formation of more stable phosphate phases, such as apatite phosphorus [34].

A small amount of $\mathrm{P}(9.20 \%)$ was found in the residual form (RP), possibly due to the incorporation of ore-P in the raw SM feedstock (Figure 3). The contents of RP in hydrochars were higher than those in raw SM, and the percentages of RP in hydrochars fluctuated in the range of $10.13-14.80 \%$ with increasing reaction temperatures. 
On the whole, the HTC treatment, especially at higher reaction temperatures, could increase the total content of phosphorus in hydrochars. Meanwhile, the percentage of insoluble/stable $\mathrm{P}$ in hydrochar was increased, while that of the water-soluble phosphorus and $\mathrm{NaHCO}_{3}$-extractable $\mathrm{P}$ was reduced. On one hand, the HTC treatment could substantially reduce the mobility of $\mathrm{P}$ in hydrochars; on the other hand, for agricultural application, the hydrochars could not only act as an available fertilizer but also as a slow-release fertilizer [52]. From the perspective of the mobility/bioavailability and recovery rate of $P$, the reasonable HTC reaction temperature for SM might be $240^{\circ} \mathrm{C}$. The hydrochars prepared in this reaction temperature were expected to be effective for the medium and long-term growth of crops and have a lower risk of runoff and leaching losses when applied to soil as an amendment. Too high HTC reaction temperature would make the loss of active phosphorus in hydrochar very problematic.

\subsection{The Transformations of $N$ Speciation}

Table 3 presents the content of $\mathrm{N}$ in each form in raw SM feedstock and hydrochar products produced at different reaction temperatures $\left(200-280^{\circ} \mathrm{C}\right)$. Figure 4 depicts the changes in the proportion of $\mathrm{N}$ distributed in different forms.

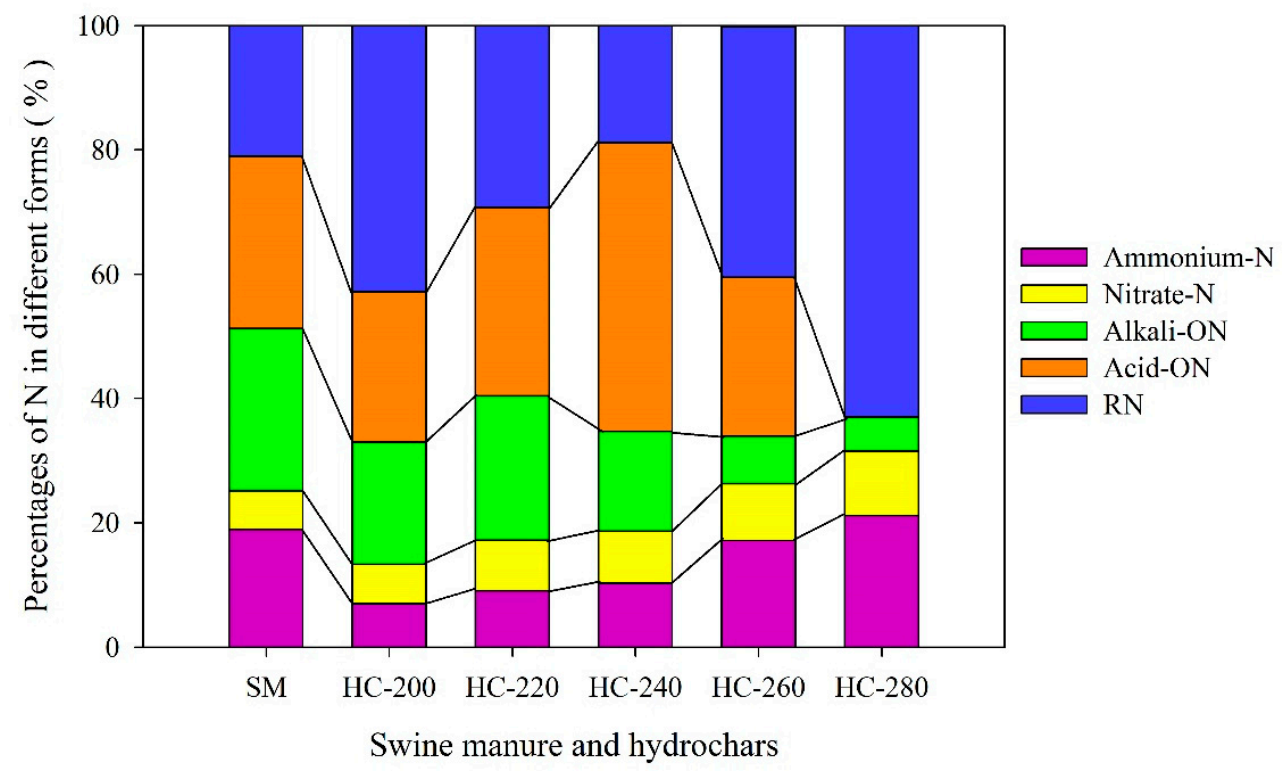

Figure 4. Changes in the forms of $\mathrm{N}$ between raw SM and hydrochars obtained at different reaction temperatures.

Table 3. Different forms of nitrogen in raw SM and hydrochars obtained at different reaction temperatures (mg/g, dry basis).

\begin{tabular}{ccccccc}
\hline Sample & $\mathbf{N H}_{\mathbf{4}}-\mathbf{N}$ & $\mathbf{N O}_{\mathbf{3}}-\mathbf{N}$ & Alkali-ON & Acid-ON & RN & $\sum \mathbf{( T N )}$ \\
\hline SM & $4.48 \pm 0.03$ & $1.47 \pm 0.06$ & $6.19 \pm 0.04$ & $6.55 \pm 0.26$ & $4.99 \pm 0.03$ & $23.68 \pm 1.04$ \\
$\mathrm{HC}-200$ & $1.12 \pm 0.02$ & $1.02 \pm 0.04$ & $3.16 \pm 0.06$ & $3.87 \pm 0.11$ & $6.87 \pm 0.12$ & $16.05 \pm 0.67$ \\
$\mathrm{HC}-220$ & $1.28 \pm 0.02$ & $1.14 \pm 0.03$ & $3.28 \pm 0.13$ & $4.27 \pm 0.16$ & $4.12 \pm 0.05$ & $14.09 \pm 0.16$ \\
$\mathrm{HC}-240$ & $1.37 \pm 0.11$ & $1.11 \pm 0.07$ & $2.14 \pm 0.15$ & $6.18 \pm 0.09$ & $2.51 \pm 0.04$ & $13.31 \pm 0.08$ \\
$\mathrm{HC}-260$ & $2.01 \pm 0.08$ & $1.07 \pm 0.12$ & $0.90 \pm 0.04$ & $2.99 \pm 0.07$ & $4.73 \pm 0.06$ & $11.72 \pm 0.14$ \\
$\mathrm{HC}-280$ & $2.29 \pm 0.07$ & $1.13 \pm 0.05$ & $0.58 \pm 0.03$ & $0.01 \pm 0.05$ & $6.82 \pm 0.15$ & $10.83 \pm 0.12$ \\
\hline
\end{tabular}

\subsubsection{Inorganic Nitrogen $\left(\mathrm{NH}_{4}-\mathrm{N}\right.$ and $\left.\mathrm{NO}_{3}-\mathrm{N}\right)$}

$\mathrm{NH}_{4}-\mathrm{N}$ and $\mathrm{NO}_{3}-\mathrm{N}$ belong to inorganic nitrogen, which can be quickly absorbed and utilized by plants, commonly seen as a quick-availability nitrogen fertilizer [4]. As seen in Table 3, the content of inorganic $\mathrm{N}$ in raw SM feedstock was $5.95 \mathrm{mg} / \mathrm{g}$, accounting for $25.1 \%$ of the total nitrogen (Figure 4). After the HTC treatment, the content of inorganic 
$\mathrm{N}$ in hydrochars decreased significantly by $48.9-74.8 \%\left(\mathrm{NH}_{4}-\mathrm{N}\right)$ and $23.1-30.6 \%\left(\mathrm{NO}_{3}-\mathrm{N}\right)$, respectively, compared with those in the raw SM feedstock. This was due to the fact that the inorganic $\mathrm{N}$ in the raw SM feedstock was mainly transferred into the aqueous product (process water) during the HTC process in the forms of $\mathrm{NH}_{4}-\mathrm{N}$ and $\mathrm{NO}_{3}-\mathrm{N}$ by hydrolysis $[4,53]$.

It was also found that the effects of reaction temperature on the content of $\mathrm{NH}_{4}-\mathrm{N}$ and $\mathrm{NO}_{3}-\mathrm{N}$ in hydrochars were different. With increasing reaction temperatures, the content of $\mathrm{NH}_{4}-\mathrm{N}$ in hydrochars showed a slightly increasing trend, while that of $\mathrm{NO}_{3}-\mathrm{N}$ changed little, consistent with the research results reported by Kruse et al. [54], who explored the fate of N during the HTC of carrot green, Chlorella pyrenoidosa, and straw. Nitrate N was negatively charged and ammonium $\mathrm{N}$ was positively charged. The chemical bonding was the main mechanism for the incorporation of $\mathrm{NH}_{4}-\mathrm{N}$ into the hydrochar during HTC, while the sorption (electrostatic adsorption/salts precipitation) was the main mechanism for the recovery of $\mathrm{NO}_{3}-\mathrm{N}$ to the hydrochar [43]. This distinct adsorbate nature might be the main cause of the difference between the changes in the situations of $\mathrm{NH}_{4}-\mathrm{N}$ and $\mathrm{NO}_{3}-\mathrm{N}$ contents.

As noted above, the inorganic nitrogen existing in hydrochars was primarily attributed to the sorption or chemical bonding to the structure of hydrochar. Hydrochar is also an effective adsorbent with a large specific surface area and a large number of charged functional groups (mainly negatively charged) $[55,56]$. To a certain extent, the increase in reaction temperature can promote the formation of pore structure and surface functional groups in hydrochar. Due to this, it was expected that the proportion of inorganic nitrogen in hydrochar increased from $13.3 \%\left(200^{\circ} \mathrm{C}\right)$ to $31.6 \%\left(280^{\circ} \mathrm{C}\right)$.

\subsubsection{Alkali-Hydrolyzed Organic Nitrogen (Alkali-ON)}

Alkali-hydrolyzed organic nitrogen (Alkali-ON) includes simple organic nitrogen, such as amino acids, amides and readily hydrolyzed protein nitrogen, which can be directly absorbed and utilized by plants in the short term. As shown in Table 3, the content of Alkali-ON in raw SM feedstock was up to $6.19 \pm 0.04 \mathrm{mg} / \mathrm{g}$, accounting for $26.1 \%$ of the total nitrogen (Figure 4). After the HTC treatment, the content of Alkali-ON in hydrochars decreased considerably. Especially at higher reaction temperatures $\left(260-280{ }^{\circ} \mathrm{C}\right)$, the content of Alkali-ON in hydrochars reduced by $85.5-90.6 \%$. These results might be due to the following reactions that occurred during the HTC process: (i) the crude proteins in raw SM were hydrolyzed to soluble polypeptides and amino acids, and then the polypeptides and amino acids were converted to organic acids, amines, ammonia and $\mathrm{CO}_{2}$ through deamination and decarboxylation processes; (ii) the polypeptide/amino acids reacted with the reducing sugar or their derivatives through typical Maillard reactions, forming more stable nitrogenous compounds $[43,57,58]$.

With the increase in reaction temperature, the content of Alkali-ON in hydrochars overall showed a decreasing trend. It slightly increased at lower reaction temperatures $\left(200-220{ }^{\circ} \mathrm{C}\right)$, from $3.16 \pm 0.06 \mathrm{mg} / \mathrm{g}$ at $200{ }^{\circ} \mathrm{C}$ up to $3.28 \pm 0.13 \mathrm{mg} / \mathrm{g}$ at $220{ }^{\circ} \mathrm{C}$, and slightly decreased at higher reaction temperatures $\left(260-280^{\circ} \mathrm{C}\right)$, from $2.14 \pm 0.15 \mathrm{mg} / \mathrm{g}$ at $240{ }^{\circ} \mathrm{C}$ down to $0.58 \pm 0.03 \mathrm{mg} / \mathrm{g}$ at $280^{\circ} \mathrm{C}$ (Table 3). This could be related to the changes in the degradation rate/kinetics of polypeptides and amino acids. The degradation of polypeptides and amino acids was reported mainly in the range of $180-260{ }^{\circ} \mathrm{C}$, and the overall rate would increase at high reaction temperatures and long reaction times. Moreover, different polypeptides/amino acids had distinct kinetics in subcritical water [59].

\subsubsection{Acid Hydrolyzed Organic Nitrogen (Acid-ON)}

Acid-hydrolyzed organic nitrogen (Acid-ON) refers to the organic nitrogen in the sample, including hexosamine nitrogen and some heterocyclic nitrogen, which could be extracted with hot hydrochloric acid. As it cannot be absorbed directly by plants, it is called slow-release nitrogen. As seen in Table 3, the content of Acid-ON in raw SM feedstock was $6.55 \pm 0.26 \mathrm{mg} / \mathrm{g}$, accounting for $27.7 \%$ of the total nitrogen (Figure 4). After the HTC 
treatment, the content of Acid-ON in hydrochar obtained at $240{ }^{\circ} \mathrm{C}$ slightly decreased by $5.7 \%$ compared with that in the raw SM feedstock. An obvious decrease in the content of Acid-ON in hydrochars produced at other reaction temperatures was found; in particular at $280{ }^{\circ} \mathrm{C}$, it decreased by $99.9 \%$, only $0.01 \mathrm{mg} / \mathrm{g}$.

The content of Acid-ON in hydrochar increased from $3.87 \pm 0.11 \mathrm{mg} / \mathrm{g}$ at $200{ }^{\circ} \mathrm{C}$ to $6.18 \pm 0.09 \mathrm{mg} / \mathrm{g}$ at $240{ }^{\circ} \mathrm{C}$. This might be due to the continuous hydrolysis of proteins and the conversion of proteins / amino acids to pyrrole- $\mathrm{N}$ by cyclization. With the increase in HTC reaction temperature, the cyclization of amine compounds from protein and amino acids, generating pyrrole- $\mathrm{N}$, was enhanced [57]. Thus, the proportion of pyrrole- $\mathrm{N}$ in hydrochar continued to increase at 200-240 ${ }^{\circ} \mathrm{C}$. Significantly, the content of Acid-ON in hydrochar decreased from $6.18 \pm 0.09 \mathrm{mg} / \mathrm{g}$ at $240{ }^{\circ} \mathrm{C}$ to $0.01 \mathrm{mg} / \mathrm{g}$ at $280^{\circ} \mathrm{C}$. This might be because the polymerization of pyrrole- $\mathrm{N}$ was improved at high reaction temperatures, resulting in the conversion of pyrrole- $\mathrm{N}$ into more stable heterocyclic nitrogen forms such as pyridines- $\mathrm{N}$ and quaternary-N, which could not be possibly extracted by hydrochloric acid $[60,61]$.

\subsubsection{Residual Nitrogen (RN)}

Residual nitrogen (RN), which generally exists in heterocyclic form, is bonded to heterocyclic or aromatic rings with a high degree of condensation. As shown in Table 3, the content of residual nitrogen (RN) in hydrochars was firstly reduced and then increased with the increase in HTC reaction temperature $\left(200-280^{\circ} \mathrm{C}\right)$. The lowest content of RN $\left(2.51 \mathrm{mg} / \mathrm{g}\right.$ ) was found at $240{ }^{\circ} \mathrm{C}$. Notably, the contents of RN in hydrochars produced at $200{ }^{\circ} \mathrm{C}$ and $280{ }^{\circ} \mathrm{C}$ were $6.87 \pm 0.12 \mathrm{mg} / \mathrm{g}$ and $6.82 \pm 0.15 \mathrm{mg} / \mathrm{g}$, respectively, higher than those in raw SM feedstock $(4.99 \pm 0.03 \mathrm{mg} / \mathrm{g})$. These results are probably due to the typical Maillard reaction of proteins and amino acids with reducing sugars or their derivatives during the HTC process, which was conducive to the binding of $\mathrm{N}$ to aromatic rings, such as pyridine- $\mathrm{N}$ and quaternary- $\mathrm{N}$ [62]. At a low reaction temperature $\left(200{ }^{\circ} \mathrm{C}\right)$, the Maillard reaction was enhanced due to the abundance of sugar and protein, and the content of quaternary ammonium salt- $\mathrm{N}$ in the hydrochar was higher, leading to the increase in $\mathrm{RN}$ in hydrochar [57]. When the reaction temperature exceeded $240{ }^{\circ} \mathrm{C}$, more pyridines- $\mathrm{N}$ and quaternary- $\mathrm{N}$ were formed, resulting in the increase in $\mathrm{RN}$ in the hydrochar $\left(240-280^{\circ} \mathrm{C}\right)$ [63].

In summary, after the HTC treatment, the total content of nitrogen retained in the hydrochars significantly reduced compared with that in raw SM feedstock (Figure 2). As depicted in Figure 4, the sum proportion of available nitrogen (Alkali-ON, nitrate $\mathrm{N}$ and ammonia N) in hydrochars decreased in comparison with that in raw SM feedstock. The hydrochar prepared at $240{ }^{\circ} \mathrm{C}$ contained the highest proportion of slow-release nitrogen (Acid-ON N) and the lowest proportion of residual nitrogen (RN). From the perspective of crop utilization and nutrient loss, moderate available nitrogen and more slow-release nitrogen in hydrochar were expected, which can be obtained by performing the HTC of SM at about $240^{\circ} \mathrm{C}$.

\subsection{Transformations of $K$ Speciation}

Table 4 presents the content of each form of $\mathrm{K}$ in raw SM feedstock and hydrochar products produced at different reaction temperatures $\left(200-280{ }^{\circ} \mathrm{C}\right)$ through the HTC treatment. Figure 5 depicts the changes in the proportion of different forms of K. 


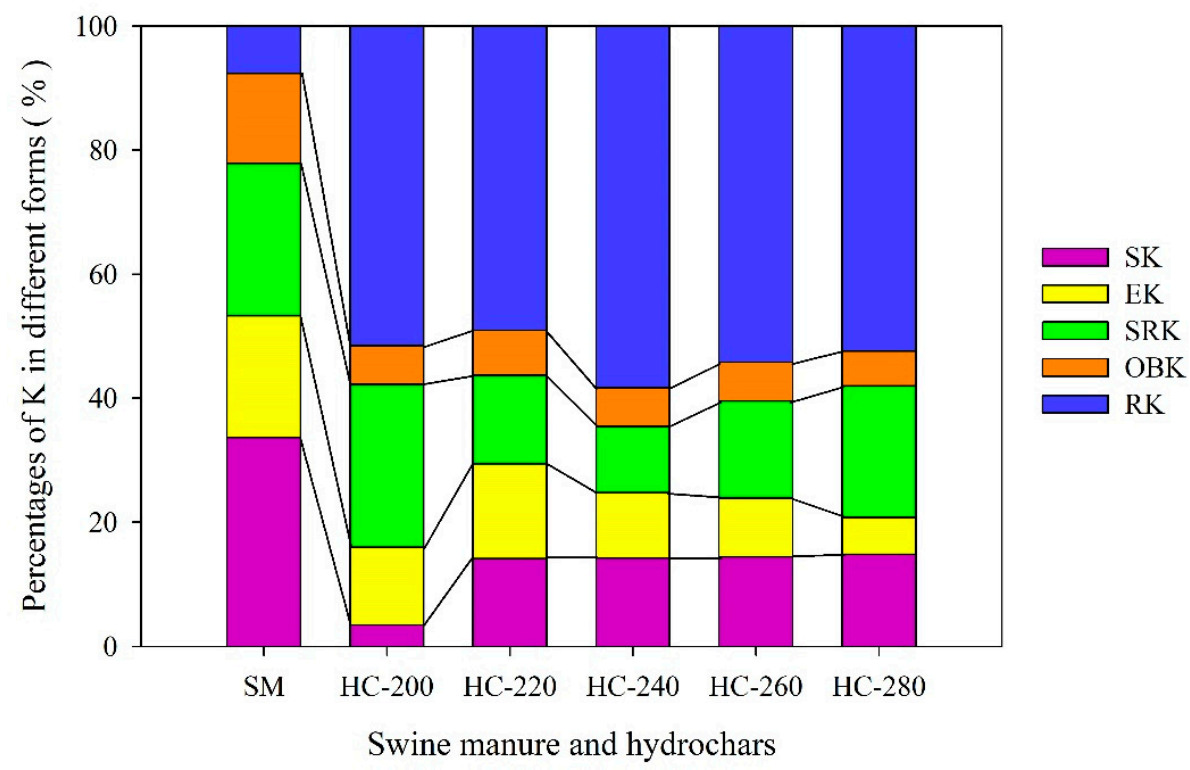

Figure 5. Changes in the forms of $\mathrm{K}$ between raw SM and hydrochars obtained at different reaction temperatures.

Table 4. Different forms of potassium in raw SM and hydrochars obtained at different reaction temperatures (mg/g, dry basis).

\begin{tabular}{ccccccc}
\hline Sample & SK & EK & SRK & OBK & RK & $\sum$ (TK) \\
\hline SM & $4.94 \pm 0.06$ & $2.88 \pm 0.14$ & $3.61 \pm 0.32$ & $2.13 \pm 0.13$ & $1.12 \pm 0.07$ & $14.68 \pm 0.72$ \\
HC-200 & $0.26 \pm 0.02$ & $0.94 \pm 0.05$ & $1.97 \pm 0.08$ & $0.47 \pm 0.01$ & $3.87 \pm 0.23$ & $7.51 \pm 0.38$ \\
HC-220 & $0.95 \pm 0.03$ & $1.03 \pm 0.03$ & $0.96 \pm 0.05$ & $0.49 \pm 0.02$ & $3.33 \pm 0.16$ & $6.73 \pm 0.29$ \\
HC-240 & $1.11 \pm 0.01$ & $0.82 \pm 0.01$ & $0.83 \pm 0.04$ & $0.49 \pm 0.01$ & $4.54 \pm 0.37$ & $7.79 \pm 0.44$ \\
HC-260 & $1.13 \pm 0.07$ & $0.74 \pm 0.02$ & $1.23 \pm 0.02$ & $0.49 \pm 0.02$ & $4.25 \pm 0.42$ & $7.84 \pm 0.55$ \\
HC-280 & $1.27 \pm 0.06$ & $0.51 \pm 0.01$ & $1.82 \pm 0.11$ & $0.48 \pm 0.03$ & $4.49 \pm 0.38$ & $8.57 \pm 0.59$ \\
\hline
\end{tabular}

\subsection{1. $\mathrm{H}_{2} \mathrm{O}$-Extractable $\mathrm{K}(\mathrm{SK})$ and Ammonium Acetate-Extractable $\mathrm{K}$ (EK)}

As seen in Table 4, the total content of $\mathrm{K}$ in raw SM feedstock reached $14.68 \pm 0.72 \mathrm{mg} / \mathrm{g}$, among which the sum content of $\mathrm{H}_{2} \mathrm{O}$-extractable $\mathrm{K}(\mathrm{SK})$ and ammonium acetate-extractable $\mathrm{K}$ (EK) was $7.82 \pm 0.20 \mathrm{mg} / \mathrm{g}$, accounting for $53.3 \%$ of the total potassium (Figure 5 ). The SK and EK are collectively referred to as available potassium, which can be directly absorbed and utilized by plants. After the HTC treatment, the contents of SK, and EK in hydrochars decreased significantly by $74.3-94.7 \%$ and $64.2-82.3 \%$, respectively, compared with those in the raw SM feedstock. Thus, the sum proportion of SK and EK in hydrochars was correspondingly reduced to $16.0-29.4 \%$ of the total potassium. The proportion of SK in hydrochar increased with the increase in reaction temperature, while that of EK firstly increased and then decreased, with a peak value $(15.3 \%)$ at $220^{\circ} \mathrm{C}$. This might be because the available $\mathrm{K}$ was mainly adsorbed on the surface of hydrochar by physical adsorption. In general, the surface pores of hydrochars would increase with the rise of reaction temperature. On the one hand, with the increase in reaction temperature, the hydrochar matrix had strong adsorption to $K$, also promoting the formation of a more stable $K$ [49].

\subsection{2. $\mathrm{HNO}_{3}$-Extractable Potassium (SRK) and Organic-Bound Potassium (OBK)}

The contents of $\mathrm{HNO}_{3}$-extractable potassium (SRK) and organic-bound potassium (OBK) in raw SM feedstock were $3.61 \pm 0.32 \mathrm{mg} / \mathrm{g}$ and $2.13 \pm 0.13 \mathrm{mg} / \mathrm{g}$, accounting for $24.6 \%$ and $14.5 \%$ of the total potassium, respectively. Both SRK and OBK can be gradually converted to effective K (available for plant growth). Compared to the raw SM feedstock, the contents of SRK and OBK in hydrochars decreased clearly by $45.9-73.4 \%$ and $77.0-$ $77.9 \%$, respectively. A total of $10.7-26.2 \%$ of $\mathrm{K}$ in hydrochars belonged to SRK and the 
percentage of OBK in hydrochars was reduced to less than $10 \%$. The proportion of SRK in hydrochar firstly decreased and then increased with increasing reaction temperatures, with the lowest value at $240{ }^{\circ} \mathrm{C}(10.7 \%$, Figure 5). The contents of SRK in hydrochars obtained at $200{ }^{\circ} \mathrm{C}$ and $280{ }^{\circ} \mathrm{C}$ were higher, i.e., $1.97 \pm 0.08 \mathrm{mg} / \mathrm{g}$ and $1.82 \pm 0.11 \mathrm{mg} / \mathrm{g}$, respectively. The reason for the former may be due to incomplete hydrolysis of SM, while the latter may be mainly due to the enrichment effect of hydrochar (i.e., reduction of easily degradable substances in SM indirectly increased the content of SRK in hydrochars). As expected, the percentage of OBK in hydrochars fluctuated in a narrow range of 5.6-7.3\% with the increase in reaction temperatures, since the content of OBK in hydrochars obtained at different reaction temperatures changed little, possibly because the organic-bound potassium was almost completely degraded at $200{ }^{\circ} \mathrm{C}$.

\subsubsection{Residual Potassium (RK)}

A small amount of residual potassium (RK, 7.6\% of total K), which was also named invalid potassium (not available for plant growth), was contained in the raw SM feedstock (Figure 5). Of note, the content of RK in hydrochars increased significantly (by 2.463.04 times compared with that in the raw SM feedstock; Table 4). The proportions of RK in hydrochars rose to $49.5-58.3 \%$ (Figure 5). The reason for the above results may be that the increase in reaction temperatures improved the formation of crystalline potassium.

In general terms, after the HTC treatment, the content of total potassium in hydrochars decreased significantly, which decreased by $41.6-54.2 \%$ compared with that in the raw SM. Most of the potassium in raw SM feedstock was converted into invalid potassium (RK) in hydrochars after the HTC treatment. In other words, only part of K in hydrochars could be used by crops. To maximize the utilization of K, the HTC of SM was suitably fixed at about $220^{\circ} \mathrm{C}$

\subsection{Prospects}

The HTC treatment of SM can promote the enrichment of phosphorus in hydrochars, and, at the same time, passivate nitrogen, phosphorus, and potassium to a certain extent. Thus, compared to the direct use of raw SM, the application of SM-derived hydrochar would resolve the nitrogen and phosphorus run-off problems by reducing the mobile phosphorus and nitrogen forms to equilibrate the plant uptake and soil retention capacity [64]. According to the content and proportion of available and slow-release nutrients $(\mathrm{N} / \mathrm{P} / \mathrm{K})$ retained in hydrochar, it was suggested that the appropriate reaction temperature for the HTC of SM should be approximately $220-240{ }^{\circ} \mathrm{C}$. It should be noted that this suggestion was only based on the chemical speciation of $\mathrm{N} / \mathrm{P} / \mathrm{K}$ nutrients in hydrochars, ignoring the soil environment, crop species and other factors. The ultimate fertility of hydrochars depended upon the interaction among hydrochars, plants, and soils.

\section{Conclusions}

After HTC treatment, phosphorus was enriched in hydrochars, while the contents of nitrogen and potassium were decreased. Of importance, the above three nutrients were all passivated to a certain extent. That is, the contents of directly soluble or active $\mathrm{N} / \mathrm{P} / \mathrm{K}$ were significantly reduced, while the contents of slow-release or stable $\mathrm{N} / \mathrm{P} / \mathrm{K}$ were increased. In this way, it can greatly alleviate environmental pollution caused by the loss of nutrients when SM is directly used in agriculture. The increase in reaction temperatures $\left(200-280^{\circ} \mathrm{C}\right)$ would promote the recovery rate of phosphorus (from $61.0 \%$ to $67.1 \%$ ) and reduce the recovery rate of nitrogen (from $39.8 \%$ to $23.0 \%$ ). From the perspective of the mobility, availability, and recovery rate of N, P, and K only, it was suggested that the HTC of SM should be carried out at about $220-240{ }^{\circ} \mathrm{C}$. There is no doubt that these results will provide an important reference for the utilization of SM-derived hydrochars as organic fertilizers.

Author Contributions: Conceptualization, J.X. and H.H.; methodology, J.X.; software, S.C.; validation, J.W., Y.W. and X.F.; formal analysis, J.W.; investigation, J.X.; resources, Y.W.; data curation, X.F.; writing—original draft preparation, J.X.; writing-review and editing, H.H.; supervision, 
H.H.; project administration, H.H. All authors have read and agreed to the published version of the manuscript.

Funding: This research was funded by the Scientific Research Fund of Jiangxi Provincial Education Department (GJJ200406), the Natural Science Foundation of Jiangxi Province, China (No. 20192BAB203019), and Jiangxi Postgraduate Innovation Special Fund Project (YC2020-S232).

Institutional Review Board Statement: Not applicable.

Informed Consent Statement: Not applicable.

Data Availability Statement: Exclude this statement.

Conflicts of Interest: The authors declare no conflict of interest.

\section{References}

1. Schommer, V.A.; Wenzel, B.M.; Daroit, D.J. Anaerobic co-digestion of swine manure and chicken feathers: Effects of manure maturation and microbial pretreatment of feathers on methane production. Renew. Energy 2020, 152, 1284-1291. [CrossRef]

2. Lin, J.C.; Mariuzza, D.; Volpe, M.; Fiori, L.; Ceylan, S.; Goldfarb, J.L. Integrated thermochemical conversion process for valorizing mixed agricultural and dairy waste to nutrient-enriched biochars and biofuels. Bioresour. Technol. 2021, 328, 124765. [CrossRef]

3. Duan, N.; Khoshnevisan, B.; Lin, C.; Liu, Z.; Liu, H. Life cycle assessment of anaerobic digestion of pig manure coupled with different digestate treatment technologies. Environ. Int. 2020, 137, 105522. [CrossRef]

4. Song, C.; Yuan, W.; Shan, S.; Ma, Q.; Zhang, H.; Wang, X.; Niazi, N.K.; Wang, H. Changes of nutrients and potentially toxic elements during hydrothermal carbonization of pig manure. Chemosphere 2020, 243, 125331. [CrossRef] [PubMed]

5. Awasthi, M.K.; Duan, Y.; Liu, T.; Awasthi, S.K.; Zhang, Z. Relevance of biochar to influence the bacterial succession during pig manure composting. Bioresour. Technol. 2020, 304, 122962. [CrossRef]

6. Zhu, F.; Hong, C.; Wang, W.; Lyu, H.; Zhu, W.; Xv, H.; Yao, Y. A microbial agent effectively reduces ammonia volatilization and ensures good maggot yield from pig manure composted via housefly larvae cultivation. J. Clean. Prod. 2020, $270,122373$. [CrossRef]

7. Wang, Y.; Zhang, J.; Li, Y.; Jia, S.; Song, Y.; Sun, Y.; Zheng, Z.H.; Yu, J.D.; Cui, Z.J.; Han, Y.Y.; et al. Methane production from the co-digestion of pig manure and corn stover with the addition of cucumber residue: Role of the total solids content and feedstock-to-inoculum ratio. Bioresour. Technol. 2020, 306, 123172. [CrossRef]

8. Ramírez-Islas, M.E.; Güereca, L.P.; Sosa-Rodriguez, F.S.; Cobos-Peralta, M.A. Environmental assessment of energy production from anaerobic digestion of pig manure at medium-scale using life cycle assessment. Waste Manag. 2020, 102, 85-96. [CrossRef]

9. Song, C.; Shan, S.; Yang, C.; Zhang, C.; Zhou, X.; Ma, Q.; Kim, Y.; Zheng, H.B.; Cao, Y.C. The comparison of dissolved organic matter in hydrochars and biochars from pig manure. Sci. Total Environ. 2020, 720, 137423. [CrossRef]

10. Lang, Q.; Chen, M.; Guo, Y.; Liu, Z.; Gai, C. Effect of hydrothermal carbonization on heavy metals in swine manure: Speciation, bioavailability and environmental risk. J. Environ. Manag. 2019, 234, 97-103. [CrossRef]

11. Zhou, C.H.; Huang, H.J.; Li, L.; Pan, Z.Q.; Xiao, X.F.; Wang, J.X. Advances in Hydrothermal Carbonization of Livestock Manure. In Sustainable Green Chemical Processes and Their Allied Applications; Nanotechnology in the Life Sciences; Inamuddin, M., Asiri, A.M., Eds.; Springer: Cham, Switzerland, 2020; pp. 183-205. [CrossRef]

12. Lee, D.J.; Jeong, K.H.; Lee, D.H.; Lee, S.H.; Jung, M.W.; Jang, Y.N.; Jo, G.G.; Kwag, J.H.; Yi, H.; Park, Y.K.; et al. Catalytic pyrolysis of swine manure using $\mathrm{CO}_{2}$ and steel slag. Environ. Int. 2019, 133, 105204. [CrossRef]

13. Li, F.; Wu, X.; Ji, W.; Gui, X.; Chen, Y.; Zhao, J.; Zhou, C.H.; Ren, T.B. Effects of pyrolysis temperature on properties of swine manure biochar and its environmental risks of heavy metals. J. Anal. Appl. Pyrolysis 2020, 152, 104945. [CrossRef]

14. Adánez-Rubio, I.; Ferreira, R.; Rio, T.; Alzueta, M.U.; Costa, M. Soot and char formation in the gasification of pig manure in a drop tube reactor. Fuel 2020, 281, 118738. [CrossRef]

15. Fernandez-Lopez, M.; López-González, D.; Puig-Gamero, M.; Valverde, J.L.; Sanchez- Silva, L. CO 2 gasification of dairy and swine manure: A life cycle assessment approach. Renew. Energy 2016, 95, 552-560. [CrossRef]

16. Lu, J.; Watson, J.; Zeng, J.; Li, H.; Zhu, Z.; Wang, M.; Zhang, Y.H.; Liu, Z.D. Biocrude production and heavy metal migration during hydrothermal liquefaction of swine manure. Process Saf. Environ. 2018, 115, 108-115. [CrossRef]

17. Wu, Q.; Wang, H.; Zheng, X.; Liu, F.; Wang, A.; Zou, D.; Yuan, J.R.; Xiao, Z.H. Thermochemical liquefaction of pig manure: Factors influencing on oil. Fuel 2020, 264, 116884. [CrossRef]

18. Shen, Y. A review on hydrothermal carbonization of biomass and plastic wastes to energy products. Biomass Bioenergy 2020, 134, 105479. [CrossRef]

19. Sharma, H.B.; Sarmah, A.K.; Dubey, B. Hydrothermal carbonization of renewable waste biomass for solid biofuel production: A discussion on process mechanism, the influence of process parameters, environmental performance and fuel properties of hydrochar. Renew. Sustain. Energy Rev. 2020, 123, 109761. [CrossRef]

20. Lucian, M.; Volpe, M.; Fiori, L. Hydrothermal Carbonization Kinetics of Lignocellulosic Agro-Wastes: Experimental Data and Modeling. Energies 2019, 12, 516. [CrossRef] 
21. Wang, J.X.; Chen, S.W.; Lai, F.Y.; Liu, S.Y.; Xiong, J.B.; Zhou, C.F.; Yu, Y.; Huang, H.J. Microwave-assisted hydrothermal carbonization of pig feces for the production of hydrochar. J. Supercrit. Fluids 2020, 162, 104858. [CrossRef]

22. Xiong, J.B.; Pan, Z.Q.; Xiao, X.F.; Huang, H.J.; Lai, F.Y.; Wang, J.X.; Chen, S.W. Study on the hydrothermal carbonization of swine manure: The effect of process parameters on the yield/properties of hydrochar and process water. J. Anal. Appl. Pyrolysis 2019, 144, 104692. [CrossRef]

23. Song, C.; Shan, S.; Müller, K.; Wu, S.; Niazi, N.K.; Xu, S.; Shen, Y.; Rinklebe, J.; Liu, D.; Wang, H. Characterization of pig manure-derived hydrochars for their potential application as fertilizer. Environ. Sci. Pollut. Res. 2018, 25, 25772. [CrossRef] [PubMed]

24. Lang, Q.; Zhang, B.; Liu, Z.; Jiao, W.; Xia, Y.; Chen, Z.; Li, D.; Ma, J.; Gai, C. Properties of hydrochars derived from swine manure by $\mathrm{CaO}$ assisted hydrothermal carbonization. J. Environ. Manag. 2019, 233, 440-446. [CrossRef]

25. Ro, K.S.; Flora, J.R.V.; Bae, S.Y.; Libra, J.A.; Berge, N.D.; Álvarez-Murillo, A.; Li, L. Properties of animal-manure-based hydrochars and predictions using published models. ACS Sustain. Chem. Eng. 2017, 5, 7317-7324. [CrossRef]

26. Lang, Q.; Zhang, B.; Liu, Z.; Chen, Z.; Xia, Y.; Li, D.; Ma, J.; Gai, C. Co-hydrothermal carbonization of corn stalk and swine manure: Combustion behavior of hydrochar by thermogravimetric analysis. Bioresour. Technol. 2019, 271, 75-83. [CrossRef]

27. Lang, Q.; Guo, Y.; Zheng, Q.; Liu, Z.; Gai, C. Co-hydrothermal carbonization of lignocellulosic biomass and swine manure: Hydrochar properties and heavy metal transformation behavior. Bioresour. Technol. 2018, 266, 242-248. [CrossRef] [PubMed]

28. Lang, Q.; Luo, H.; Li, Y.; Li, D.; Liu, Z.; Yang, T. Thermal behavior of hydrochar from co-hydrothermal carbonization of swine manure and sawdust: Effect of process water recirculation. Sustain. Energy Fuels 2019, 3, 2329-2336. [CrossRef]

29. Lang, Q.; Zhang, B.; Li, Y.; Liu, Z.; Jiao, W. Formation and toxicity of polycyclic aromatic hydrocarbons during CaO assisted hydrothermal carbonization of swine manure. Waste Manag. 2019, 100, 84-90. [CrossRef] [PubMed]

30. Jin, H.; Yan, D.; Zhu, N.; Zhang, S.; Zheng, M. Immobilization of metal(loid)s in hydrochars produced from digested swine and dairy manures. Waste Manag. 2019, 88, 10-20. [CrossRef]

31. Gascó, G.; Paz-Ferreiro, J.; Álvarez, M.L.; Saa, A.; Méndez, A. Biochars and hydrochars prepared by pyrolysis and hydrothermal carbonisation of pig manure. Waste Manag. 2018, 79, 395-403. [CrossRef]

32. Liu, Y.; Yao, S.; Wang, Y.; Lu, H.; Brar, S.K.; Yang, S. Bio- and hydrochars from rice straw and pig manure: Inter-comparison. Bioresour. Technol. 2017, 235, 332-337. [CrossRef]

33. Cao, X.; Ro, K.S.; Chappell, M.; Li, Y.; Mao, J. Chemical structures of swine-manure chars produced under different carbonization conditions investigated by advanced solid-state ${ }^{13} \mathrm{C}$ nuclear magnetic resonance (NMR) spectroscopy. Energy Fuels 2011, 25, 388-397. [CrossRef]

34. Huang, R.; Fang, C.; Zhang, B.; Tang, Y. Transformations of phosphorus speciation during (hydro)thermal treatments of animal manures. Environ. Sci. Technol. 2018, 52, 3016-3026. [CrossRef]

35. Ekpo, U.; Ross, A.B.; Camargo-Valero, M.A.; Fletcher, L.A. Fletcher, Influence of pH on hydrothermal treatment of swine manure: Impact on extraction of nitrogen and phosphorus in process water. Bioresour. Technol. 2016, 214, 637-644. [CrossRef]

36. Huang, R.; Fang, C.; Lu, X.; Jiang, R.; Tang, Y. Transformation of phosphorus during (hydro)thermal treatments of solid biowastes: Reaction mechanisms and implications for P reclamation and recycling. Environ. Sci. Technol. 2017, 51, 10284-10298. [CrossRef] [PubMed]

37. Qaramaleki, S.V.; Villamil, J.A.; Mohedano, A.F.; Coronella, C.J. Factors affecting solubilization of phosphorus and nitrogen through hydrothermal carbonization of animal manure. ACS Sustain. Chem. Eng. 2020, 8, 12462-12470. [CrossRef]

38. Pansu, M.; Gautheyrou, J. (Eds.) Organic Forms of Nitrogen, Mineralizable Nitrogen (and Carbon). In Handbook of Soil Analysis: Mineralogical, Organic and Inorganic Methods; Springer: Berlin/Heidelberg, Germany, 2006; pp. 497-547. [CrossRef]

39. Andrist-Rangel, Y.; Simonsson, M.; Andersson, S.; Öborn, I.; Hillier, S. Mineralogical budgeting of potassium in soil: A basis for understanding standard measures of reserve potassium. J. Plant Nutr. Soil Sci. 2006, 169, 605-615. [CrossRef]

40. Soil Agrochemical Analysis; Bao, S.D. (Ed.) China Agricultural Publishing House: Beijing, China, 2000; pp. 99-114.

41. Li, J.; Niu, L.; Zhang, Q.; Di, H.; Hao, J. Impacts of long-term lack of potassium fertilization on different forms of soil potassium and crop yields on the North China Plains. J. Soils Sediments 2017, 17, 1607-1617. [CrossRef]

42. Zhang, S.; Zhang, X.; Liu, X.; Liu, W.; Liu, Z. Spatial distribution of soil nutrient at depth in black soil of Northeast China: A case study of soil available potassium. Nutr. Cycl. Agroecosystems 2013, 95, 319-331. [CrossRef]

43. Alhnidi, M.J.; Wüst, D.; Funke, A.; Hang, L.; Kruse, A. Fate of nitrogen, phosphate, and potassium during hydrothermal carbonization and the potential for nutrient recovery. ACS Sustain. Chem. Eng. 2020, 8, 15507-15516. [CrossRef]

44. Belete, Y.Z.; Mau, V.; Yahav Spitzer, R.; Posmanik, R.; Jassby, D.; Iddya, A.; Kassem, N.; Tester, J.W.; Gross, A. Hydrothermal carbonization of anaerobic digestate and manure from a dairy farm on energy recovery and the fate of nutrients. Bioresour. Technol. 2021, 333, 125164. [CrossRef] [PubMed]

45. Huang, R.; Tang, Y. Evolution of phosphorus complexation and mineralogy during (hydro)thermal treatments of activated and anaerobically digested sludge: Insights from sequential extraction and P K-edge XANES. Water Res. 2016, 100, 439-447. [CrossRef]

46. Funke, A. Fate of plant available nutrients during hydrothermal carbonization of digestate. Chem. Ing. Tech. 2015, 87, 1713-1719. [CrossRef]

47. Pagliari, P.; Laboski, C. Dairy manure treatment effects on manure phosphorus fractionation and changes in soil test phosphorus. Biol. Fertil. Soils 2013, 49, 987-999. [CrossRef] 
48. Pagliari, P.H. Variety and solubility of phosphorus forms in animal manure and their effects on soil test phosphorus. In Applied Manure and Nutrient Chemistry for Sustainable Agriculture and Environment; He, Z., Zhang, H., Eds.; Springer: Dordrecht, The Netherlands, 2014; pp. 141-161. [CrossRef]

49. Ghanim, B.M.; Kwapinski, W.; Leahy, J.J. Speciation of nutrients in hydrochar produced from hydrothermal carbonization of poultry litter under different treatment conditions. ACS Sustain. Chem. Eng. 2018, 6, 11265-11272. [CrossRef]

50. Dai, L.; Tan, F.; Wu, B.; He, M.; Wang, W.; Tang, X.; Hu, Q.H.; Zhang, M. Immobilization of phosphorus in cow manure during hydrothermal carbonization. J. Environ. Manag. 2015, 157, 49-53. [CrossRef] [PubMed]

51. Pardo, P.; López-Sánchez, J.F.; Rauret, G. Relationships between phosphorus fractionation and major components in sediments using the SMT harmonised extraction procedure. Anal. Bioanal. Chem. 2003, 376, 248-254. [CrossRef]

52. Whalen, J.K.; Chang, C. Phosphorus accumulation in cultivated soils from long-term annual applications of cattle feedlot manure. J. Environ. Qual. 2001, 30, 229-237. [CrossRef] [PubMed]

53. Zhao, P.; Chen, H.; Ge, S.; Yoshikawa, K. Effect of the hydrothermal pretreatment for the reduction of NO emission from sewage sludge combustion. Appl. Energy 2013, 111, 199-205. [CrossRef]

54. Kruse, A.; Koch, F.; Stelzl, K.; Wüst, D.; Zeller, M. Fate of nitrogen during hydrothermal carbonization. Energy Fuel 2016, 30, 8037-8042. [CrossRef]

55. Regmi, P.; Garcia-Moscoso, J.L.; Kumar, S.; Cao, X.; Mao, J.; Schafran, G. Removal of copper and cadmium from aqueous solution using switchgrass biochar produced via hydrothermal carbonization process. J. Environ. Manag. 2012, 109, 61-69. [CrossRef]

56. Ferrentino, R.; Ceccato, R.; Marchetti, V.; Andreottola, G.; Fiori, L. Sewage sludge hydrochar: An option for removal of methylene blue from wastewater. Appl. Sci. 2020, 10, 3445. [CrossRef]

57. Wang, T.; Zhai, Y.; Zhu, Y.; Peng, C.; Xu, B.; Wang, T.; Li, C.T.; Zeng, G.M. Influence of temperature on nitrogen fate during hydrothermal carbonization of food waste. Bioresour. Technol. 2018, 247, 182-189. [CrossRef]

58. Wu, K.; Zhang, X.; Yuan, Q. Effects of process parameters on the distribution characteristics of inorganic nutrients from hydrothermal carbonization of cattle manure. J. Environ. Manag. 2018, 209, 328-335. [CrossRef]

59. Zhu, G.Y.; Zhu, X.; Xiao, Z.B.; Zhou, R.J.; Feng, N.N.; Niu, Y.W. A review of amino acids extraction from animal waste biomass and reducing sugars extraction from plant waste biomass by a clean method. Biomass Convers. Biorefinery 2015, 5, 309-320. [CrossRef]

60. Oliver-Tomas, B.; Hitzl, M.; Owsianiak, M.; Renz, M. Evaluation of hydrothermal carbonization in urban mining for the recovery of phosphorus from the organic fraction of municipal solid waste. Resour. Conserv. Recycl. 2019, 147, 111-118. [CrossRef]

61. Falco, C.; Sevilla, M.; White, R.J.; Rothe, R.; Titirici, M.M. Renewable nitrogen-doped hydrothermal carbons derived from microalgae. ChemSusChem 2012, 5, 1834-1840. [CrossRef]

62. Aragón-Briceño, C.I.; Pozarlik, A.K.; Bramer, E.A.; Niedzwiecki, L.; Pawlak-Kruczek, H.; Brem, G. Hydrothermal carbonization of wet biomass from nitrogen and phosphorus approach: A review. Renew. Energy 2021, 171, 401-415. [CrossRef]

63. Funke, A.; Mumme, J.; Koon, M.; Diakité, M. Cascaded production of biogas and hydrochar from wheat straw: Energetic potential and recovery of carbon and plant nutrients. Biomass Bioenergy 2013, 58, 229-237. [CrossRef]

64. Wang, L.; Chang, Y.; Liu, Q. Fate and distribution of nutrients and heavy metals during hydrothermal carbonization of sewage sludge with implication to land application. J. Clean. Prod. 2019, 225, 972-983. [CrossRef] 